\title{
EFFECT OF TORREFACTION PROCESS ON PROPERTIES OF PALM KERNEL SHELL BY USING TORREFACTION ROTARY KILN
}

\author{
NATTARAT CHUTWIBOONKUN, NAT THUCHAYAPONG \& NATTAWUT THARAWADEE \\ Department of Mechanical Engineering, Faculty of Engineering and Industrial Technology, \\ Silpakorn University, Thailand
}

\begin{abstract}
This research studies the effect of the torrefaction process by using a rotary kiln on torrefied biomass properties. The torrefaction rotary kiln and palm kernel shell were used in this research. An investigation focused on and studied the palm kernel shell in the torrefaction process using a torrefaction rotary kiln. The solid phase (biochar), liquid phase (condensed liquid), and gas-phase ratio were clarified. The feasibility of a palm kernel shell as renewable energy was investigated. Palm kernel shell waste is abundant in the southern region of Thailand. The waste from palm kernel shells is around 500,000 tons per year and increasing every year. The palm kernel shell (raw material) has an advantage as high calorific value. Moreover, the palm kernel shell is potentially fuel in the boiler (instead of charcoal) and is widely used in many power plants. The value of the palm kernel shell depends on the quality of biomass. To find an optimum condition in the palm kernel shell industrial process, the temperature of the torrefaction process and rotation speed were set at $230,250,270^{\circ} \mathrm{C}$, and $1,2,3 \mathrm{rpm}$, respectively. The product yield, characteristics of torrefied biomass, moisture content, particle distribution, mass yield, and energy yield were reported. From the result, the solid phase product was decreased when the torrefaction temperature increased, the fluid phase product and gas-phase product were increased. The particle size after torrefaction was smaller than raw biomass. The mass yield and energy yield decreased when the torrefaction was increased. On the other hand, the mass yield and energy yield increased when rotation speed was increased. It was concluded that the optimum condition for palm kernel shell in torrefaction process was $230^{\circ} \mathrm{C}$ with $3 \mathrm{rpm}$. The torrefaction process can improve the properties and combustion performance of biomass. The palm kernel shell was a suitable fuel and co-burning in the economic energy plant in the torrefaction process with the optimum condition.
\end{abstract}

Keywords: palm kernel shell, biomass, torrefaction, rotary kiln, HHV, energy yield, particle size.

\section{INTRODUCTION}

At present, renewable energy was widely used in industrial plants. Nowadays, solar, wind, and biomass waste were increasingly used in many countries. Biomass plays a vital role in Thailand. Much of the agricultural waste from the plant was discarded in Thailand. However, the potential of biomass energy in Thailand was remarkable to study. The biomass has some weaknesses, such as low calorific value, low bulk density, low energy density, and high moisture content. The biomass properties need to be improved to produce higher quality fuel. The products from the torrefied process were suitable for combustion applications and transportation.

For many years, one of the most effective processes for upgrading biomass is torrefaction. This is a thermochemical process conducted at a low temperature ranging from 200 to $300^{\circ} \mathrm{C}$ and at a low heating rate [1]. Dehydration, decarboxylation, and dehydroxylation reactions occurred during torrefaction. The $\mathrm{O} / \mathrm{C}$ and $\mathrm{H} / \mathrm{C}$ ratios were lower when preparing with raw biomass [2].

After this process, most of the biomass weaknesses were reduced. The residence time and temperature of the torrefaction process have more effect on a product by torrefaction process. 
Many researchers have studied the effect of temperature on torrefied biomass. It was found that when the temperature was increased, moisture content, HHV, ash, mass yield, and energy yield has been significantly changed [3]. On the other hand, many researchers have studied the effect of residence on the torrefied biomass. It was found that the HHV of the torrefied biomass rapidly increased when residence time increased. When a certain residence time was reached, the HHV tended to asymptote to a constant value.

Many types of reactors were used for torrefaction reactors. It has many kinds of reactors for the torrefaction process [4]. The fixed bed torrefaction reactor is the simplest reactor. The reactor was filled with biomass and heated up from the heat source outside the surface of the reactor. Except for the ordinary heat source, the microwave torrefaction reactor was used for the torrefaction process. The electromagnetic wave vibrated the water molecules inside biomass. Then, the temperature of biomass increased. A fluidized bed torrefaction reactor is the one type of torrefaction reactor. The raw biomass was placed on the grate. The hot gas was flown from the bottom through the raw biomass bed. The raw biomass floated and behaved like a fluid. However, the torrefied biomass from the torrefaction reactor, as mentioned before, was a non-uniform product. The rotary kiln was applied to use for the torrefaction process [5]. The product from the rotary kiln was uniform when comparing with the previous reactor.

At present, palm kernel shell waste is abundant in the southern region of Thailand. The waste from palm kernel shells was around 500,000 tons per year and increasing every year. The palm kernel shell (raw material) was an advantaged as high calorific value [6]. Moreover, the palm kernel shell has the potential as fuel in the boiler. The value of the palm kernel shell depends on the quality of biomass. One of the large biomass potentials is a by-product of the oil palm industry, such as palm kernel shells and empty fruit bunches. From this production, the biomass produces from the palm oil industry includes empty fruit bunches $(23 \%)$, mesocarp fibers $(12 \%)$, and palm kernel shells $(5 \%)$ from every ton of fresh fruit bunches [7]. Many researchers were studied torrefied palm kernel shells. Palm kernel shell after torrefaction process has High HHV, high energy yield, and the potential to be used as a fuel after torrefaction. However, the knowledge of palm kernel shell in the improvement process lacked.

This research focused on and studied the palm kernel shell in the torrefaction process using a torrefaction rotary kiln. The solid phase (biochar), liquid phase (condensed liquid), and gas-phase ratio were clarified. The feasibility and optimum condition of a palm kernel shell as renewable energy was investigated.

\section{METHODOLOGY AND MATERIAL}

\subsection{Raw material preparation}

A palm kernel shell was used in this research. The raw material was mince to $5 \mathrm{~mm}$ to reduce its size. The initial moisture content of raw material was $14 \%$ wet basis. An initial condition of raw biomass was shown in Table 1.

\subsection{The torrefaction process and equipment}

Torrefaction rotary kiln was used for the torrefaction, as shown in Fig. 1. The pilot torrefied rotary kiln consists of a rotating cylinder. The cylinder is $6 \mathrm{~m}$ in length and $0.3 \mathrm{~m}$ in diameter. The two L-shape lifters were attached inside the to mix biomass easily and uniformly flow. 
Table 1: Raw material preparation.

\begin{tabular}{|c|c|}
\hline Parameters & Condition \\
\hline Biomass & Palm kernel shell \\
\hline Initial moisture content & $14 \%$ \\
\hline Particle size & $\leq 5 \mathrm{~mm}$ \\
\hline HHV (raw material) & $17.40 \mathrm{MJ} / \mathrm{kg}$ \\
\hline
\end{tabular}

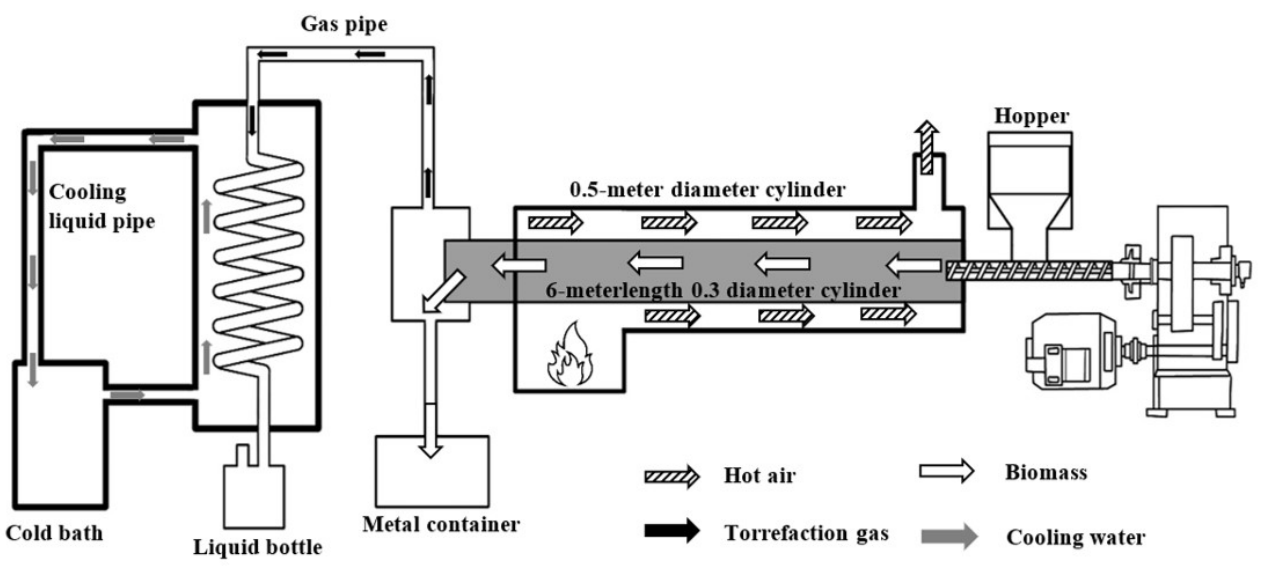

Figure 1: Rotary kiln for torrefaction process and system for collected liquid phase for the torrefaction process.

The cylinder was used to convey biomass and cover with a $0.5 \mathrm{~m}$ diameter cylinder. The hopper was used in a feeding system (feed rate $4 \mathrm{~kg} /$ hour). Liquid petroleum gas (LPG) was used for the heat source. The rotation speed was varied at 1,2, and $3 \mathrm{rpm}$. The slope of the rotary kiln was fixed at $2^{\circ}$ from horizontal. The temperature profile inside the rotary kiln was monitored by a data logger (midi logger GL 820 accuracy $\pm 0.05 \%$ ) and thermocouple type $\mathrm{K}$ (accuracy $\pm 1^{\circ} \mathrm{C}$ ). The reactor was placed at the end of the rotary kiln. The reactor was heated up to torrefaction temperature. After the temperature of the reactor was in a steadystate, the raw material was fed into the rotary kiln ( $4 \mathrm{~kg} /$ hour $)$. The biomass and hot air were counter-current flow and not direct contact (to prevent oxidation).

Metal container was used to collect torrefied biomass (solid phase). The container is hermetically closed to avoid the oxidation of the product during cooling. The end of the rotary kiln has a smokestack to release the liquid and gas. The smokestack was connected with the cooling system. The liquid phase from the torrefaction process was collected with the glass bottle. The copper pipe was contained in the cooling tank. The water in the cooling tank was controlled at $10 \pm 1^{\circ} \mathrm{C}$ by a cold bath (eyela cool ace ca-1111). The end of the copper pipe was connected with a glass bottle to collect the fluid after condensed. The system for collecting the liquid phase from torrefaction was shown in Fig. 1. 


\subsection{Methodology}

\subsubsection{Particle size distribution}

Particle size distribution was determined by using the ASTM D422 standard. Particle size was tested by six layers sieve analysis (sieve size 3.35 to $0.425 \mathrm{~mm}$ ). Particle size distribution can be calculated in eqn (1).

$$
\operatorname{SIEVE}(\%)=(\mathrm{S} / \mathrm{W}) \times 100(\%),
$$

where $\mathrm{S}$ is the weight of sieve $(\mathrm{g})$ and $\mathrm{W}$ is total weight $(\mathrm{g})$

\subsubsection{Moisture content}

Moisture content was determined by using the ASTM D2216-10 standard. The heating oven collected moisture content data (Redline by Binder 230 -volt, accuracy $\pm 0.3^{\circ} \mathrm{C}$ ). The biomass was drying at $105^{\circ} \mathrm{C}$ for 24 hours. Moisture content can be calculated as follows:

$$
\mathrm{M}=\left(\left(\mathrm{W}_{0}-\mathrm{W}_{\mathrm{f}}\right) / \mathrm{W}_{0}\right) \times 100,
$$

where $\mathrm{M}$ is moisture content $(\%) ; \mathrm{W}_{0}$ is the initial weight $(\mathrm{g})$; and $\mathrm{W}_{\mathrm{f}}$ is the final weight $(\mathrm{g})$.

2.3.3 High heating value (HHV)

A higher heating value is the amount of energy produced by the combustion of fuel. The higher heating value of the briquette was measured with an oxygen bomb calorimeter (Parr 1341).

2.3.4 Mass and energy yield

The mass yield and energy yield can be calculated using the following equation [8]:

$$
\mathrm{Y}_{\mathrm{m}}=\left(\mathrm{M}_{\mathrm{t}} / \mathrm{M}_{\mathrm{r}}\right) \times 100 \%,
$$

where $Y_{m}$ is mass yield (\%); $M_{t}$ is a mass of torrefied biomass $(\mathrm{g})$; and $\mathrm{M}_{\mathrm{r}}$ is a mass of raw material $(\mathrm{g})$.

$$
\mathrm{Y}_{\mathrm{e}}=\left(\mathrm{HHV}_{\mathrm{t}} / \mathrm{HHV}_{\mathrm{r}}\right) \times \mathrm{Y}_{\mathrm{m}}
$$

where Ye is energy yield (\%); $\mathrm{HHV}_{\mathrm{t}}$ is higher heating value of torrefied biomass $(\mathrm{MJ} / \mathrm{kg})$; and $\mathrm{HHV}_{\mathrm{r}}$ is higher heating value of raw material $(\mathrm{MJ} / \mathrm{kg})$.

\subsubsection{Conservation of mass}

$$
\begin{gathered}
100=\mathrm{Y}_{\text {solid }}+\mathrm{Y}_{\text {liquid }}+\mathrm{Y}_{\text {gas }} \\
\mathrm{Y}_{\text {solid }}=\mathrm{M}_{\text {solid }} / \mathrm{M}_{\text {total },} \\
\mathrm{Y}_{\text {liquid }}=\mathrm{M}_{\text {liquid }} / \mathrm{M}_{\text {total }}
\end{gathered}
$$

where $\mathrm{M}_{\text {total }}$ is mass of raw material $(\mathrm{kg}) ; \mathrm{M}_{\text {solid }}$ is a mass of solid phase $(\mathrm{kg}) ; \mathrm{M}_{\text {liquid }}$ is a mass of liquid phase $(\mathrm{kg}) ; \mathrm{Y}_{\text {solid }}$ is yield of solid phase (\%); $\mathrm{Y}_{\text {liquid }}$ is yield of liquid phase (\%); and $\mathrm{Y}_{\text {gas }}$ is yield of gas phase (\%).

The yield of gas was calculated by subtracting the yield of solid and liquid from $100 \%$ (raw material). 


\section{RESULTS AND DISCUSSIONS}

\subsection{Product yield}

Fig. 2 shows the effect of temperature on a product yield of torrefied biomass. The product yield of a solid phase (bio-coal), liquid phase, and gas phase (non-condensable gas) of biomass after the torrefaction process was investigated. The mass of raw biomass was equal to $100 \%$. The percentage of the gas phase was calculated from eqn (5). The temperature had a significant effect on the palm kernel shell torrefaction, as shown in Table 2. In this result, the amount of solid phase product was decreased when temperature increased because the component of biomass was disintegrated during the torrefaction process [9]-[11]. When the torrefaction temperature was $230^{\circ} \mathrm{C}$, the palm kernel shell's mass loss was very low $(22.40 \%)$ because the most unstable hemicellulose in the palm kernel has not been decomposed at this torrefaction temperature.

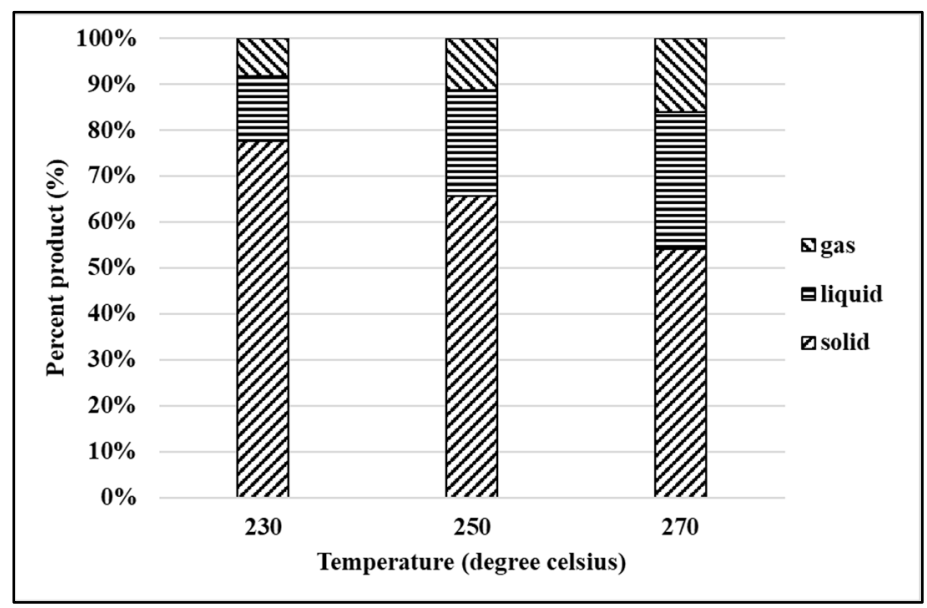

Figure 2: Product yield of torrefied biomass.

Table 2: Product yield of torrefied biomass.

\begin{tabular}{cccc}
\hline \multirow{2}{*}{ Temperature $\left({ }^{\circ} \mathrm{C}\right)$} & \multicolumn{3}{c}{ Yield (\%) } \\
\cline { 2 - 4 } & $\begin{array}{c}\text { Solid phase } \\
(\text { bio-coal) }\end{array}$ & Liquid phase & $\begin{array}{c}\text { Gas phase } \\
\text { (non-condensable gas) }\end{array}$ \\
\hline 230 & 77.60 & 14.20 & 8.20 \\
250 & 65.67 & 22.93 & 11.40 \\
270 & 54.10 & 29.87 & 16.03 \\
\hline
\end{tabular}

Nevertheless, when the torrefaction temperature was increased to $250^{\circ} \mathrm{C}$ and $270^{\circ} \mathrm{C}$, the palm kernel shell's mass loss was also increased. The pyrolysis reaction was intensified at higher torrefaction temperature, and more volatile matter was released. The liquid phase product was increased at high temperatures. The moisture content, volatile matter, hemicellulose, and cellulose were disintegrated at high temperatures. The torrefied biomass from the rotary kiln was a uniform product. Fig. 3(a) shows the raw biomass, 3(b), 3(c), and 
$3(\mathrm{~d})$ show the solid phase product from torrefaction at $230^{\circ} \mathrm{C}, 250^{\circ} \mathrm{C}$, and $270^{\circ} \mathrm{C}$, respectively. The raw biomass is a deep brown color. When the torrefaction temperature increased, the carbon content increased, and the physical color became black. Then, the biomass after torrefaction was darker and smaller than raw biomass.

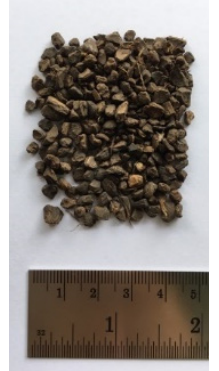

(a)

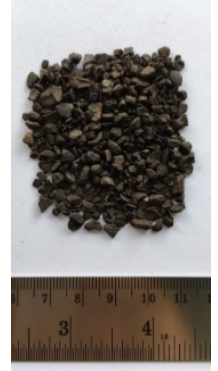

(b)

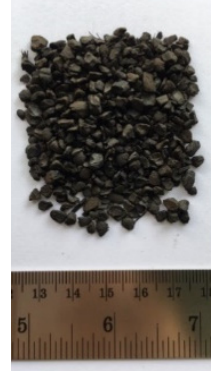

(c)

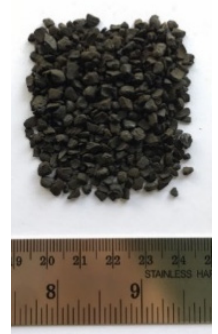

(d)

Figure 3: Characteristic of solid-phase product from torrefied biomass.

A similar result has also been observed by other researchers [12], [13]. The fluid product after condensed with cooling water at $10^{\circ} \mathrm{C}$, as shown in Fig. 4. Fig. 4(a), 4(b), and 4(c) show the liquid product from torrefaction at $230^{\circ} \mathrm{C}, 250^{\circ} \mathrm{C}$, and $270^{\circ} \mathrm{C}$, respectively. The liquid products contained large amounts of water. A part of the water came from the palm kernel by itself. The other part originated from the thermal decomposition of the organic components, especially hemicellulose. With the increase in torrefaction temperature, the water content in the liquid product gradually decreased, which was due to more tar produced. The liquid phase product at $270^{\circ} \mathrm{C}$ was stickier when compared with $230^{\circ} \mathrm{C}$ and $250^{\circ} \mathrm{C}$. The color of the liquid at $270^{\circ} \mathrm{C}$ was turned to black because it has more tar in the component of the liquid phase product. The volume of the liquid phase was increased when the temperature increased. The trend of solid phase and liquid phase were the same with a previous study [8]. The moisture content of raw biomass and torrefied biomass was shown in Fig. 5. The moisture content of torrefied biomass was lower than raw biomass. The moisture content of raw biomass was $14.05 \%$. The moisture content of torrefied biomass was $1.31 \%$. The moisture of torrefied biomass was less than raw biomass, $90.80 \%$. A similar result has also been observed by others [13].

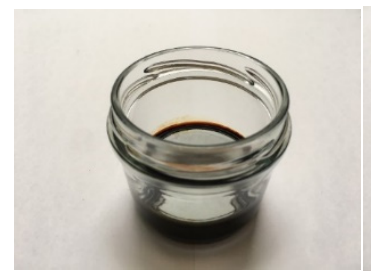

(a)

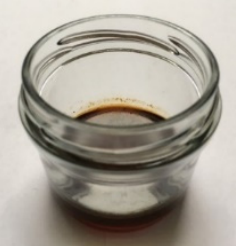

(b)

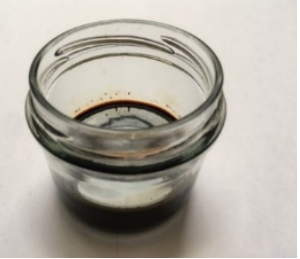

(c)

Figure 4: Characteristic of liquid phase product from torrefied biomass. (a) At $230^{\circ} \mathrm{C}$; (b) At $250^{\circ} \mathrm{C}$; and (c) At $270^{\circ} \mathrm{C}$. 


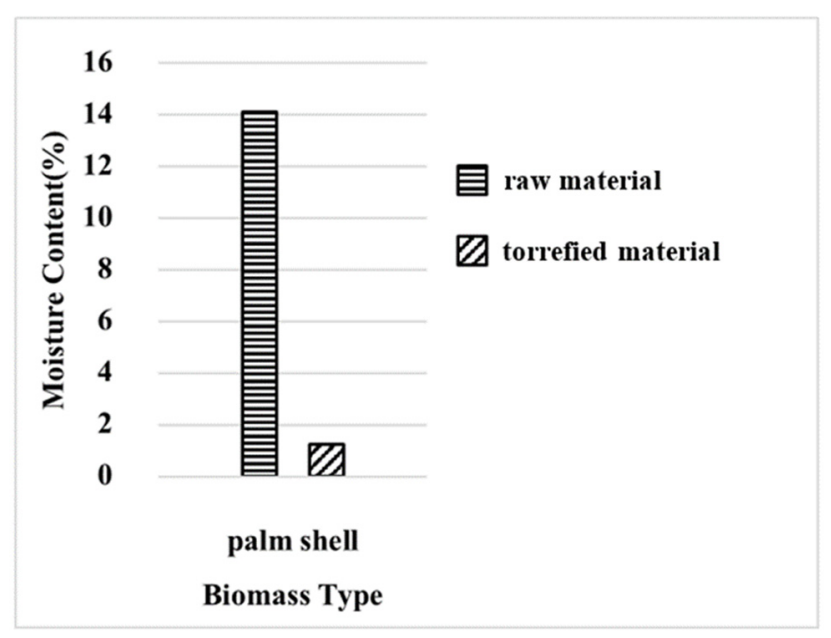

Figure 5: Moisture content.

\subsection{Particle size distribution}

The particle size distribution of raw material and torrefied biomass were investigated. Fig. 6(a), 6(b) and 6(c) show particle distribution at 1,2 and $3 \mathrm{rpm}$ respectively. The highest amount of particle size in raw material was observed at $1.7-3.35 \mathrm{~mm}$. After the torrefaction process, the particle size of torrefied biomass was smaller than raw biomass, and the amount of percentage of large particles decrease when the torrefaction temperature increase. The degradation of biomass has occurred during the torrefaction process. The degradation was a decomposition reaction of cellulose, hemicellulose, and lignin in biomass [16]. At $1 \mathrm{rpm}$, the large particle was sharply decreasing $(3.35<\mathrm{mm})$, and the smaller particle was slightly increased $(0.85-1.7 \mathrm{~mm}) .2 \mathrm{rpm}$ and $3 \mathrm{rpm}$ have the same trend with $1 \mathrm{rpm}$. It was concluded that the particle size of biomass after the torrefaction process was smaller than raw biomass. Fig. 6(d), 6(e) and 6(f) show particle size distribution at $230^{\circ} \mathrm{C}, 250^{\circ} \mathrm{C}$ and $270^{\circ} \mathrm{C}$, respectively. The residence time of the process increase when the rotation speed of the rotary kiln decrease. The rotary kiln's biomass was heat longer than the high rotation speed at the low rotation speed. As a result, the degradation was increased depend on residence time and temperature. The smaller particle size was an increase when the rotation speed decrease or increase temperature. At $230^{\circ} \mathrm{C}$, the large particle was sharply decreasing $(3.35<\mathrm{mm})$, and the smaller particle was slightly increased $(0.85-1.7 \mathrm{~mm})$. At $250^{\circ} \mathrm{C}$ and $270^{\circ} \mathrm{C}$ have the same trend as $230^{\circ} \mathrm{C}$. It was concluded that the torrefaction temperature and rotation speed affect particle distribution [16]. The large particle was decreasing at the high temperature and low rotation speed, and the small particle was increased.

\subsection{Calorific value}

HHV of the torrefied product was an important parameter. The higher HHV, the more energy can be stored or transported at the same amount of volume. From the result, the HHV of the product after torrefaction was increased [12], [14]. The highest HHV was found at $3 \mathrm{rpm}$ $270^{\circ} \mathrm{C}$. The highest HHV was increasing to 1.64 times when compared with raw material. The HHV of the torrefied product was shown in Table 3. 


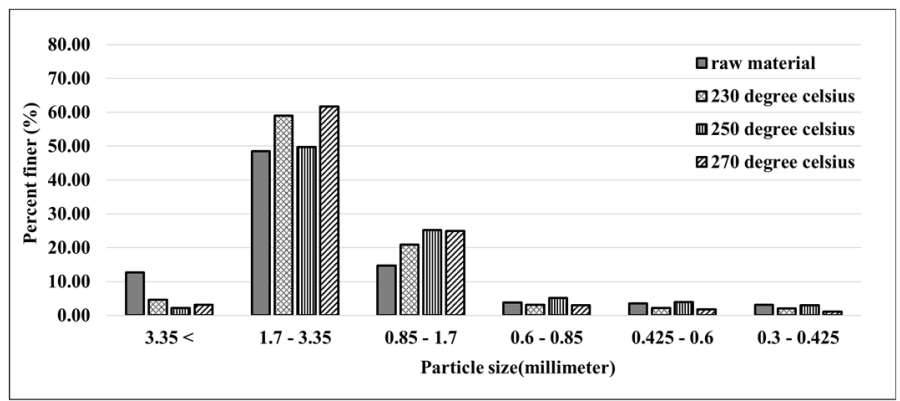

(a)

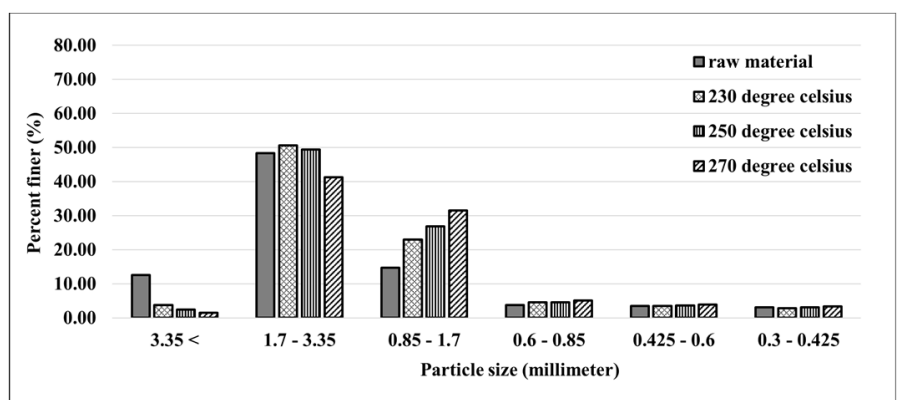

(b)

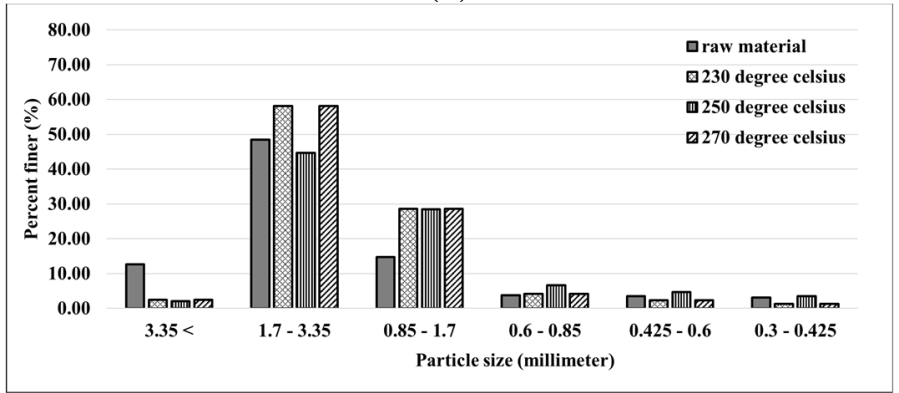

(c)

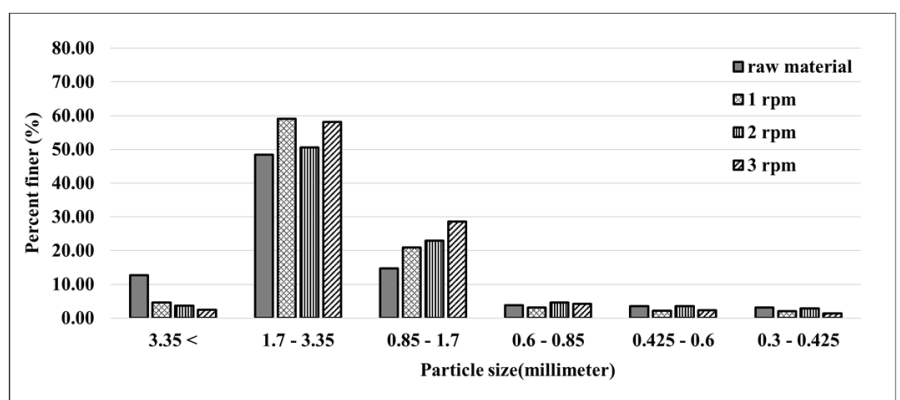

(d)

Figure 6: (a) Particle size distribution at $1 \mathrm{rpm}$; (b) Particle size distribution at $2 \mathrm{rpm}$;

(c) Particle size distribution at $3 \mathrm{rpm}$; (d) Particle size distribution at $230^{\circ} \mathrm{C}$;

(e) Particle size distribution at $250^{\circ} \mathrm{C}$; and (f) Particle size distribution at $270^{\circ} \mathrm{C}$. 


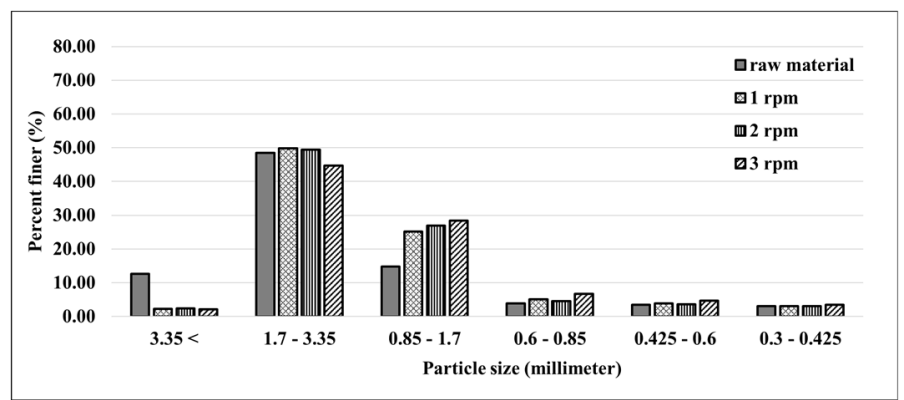

(e)

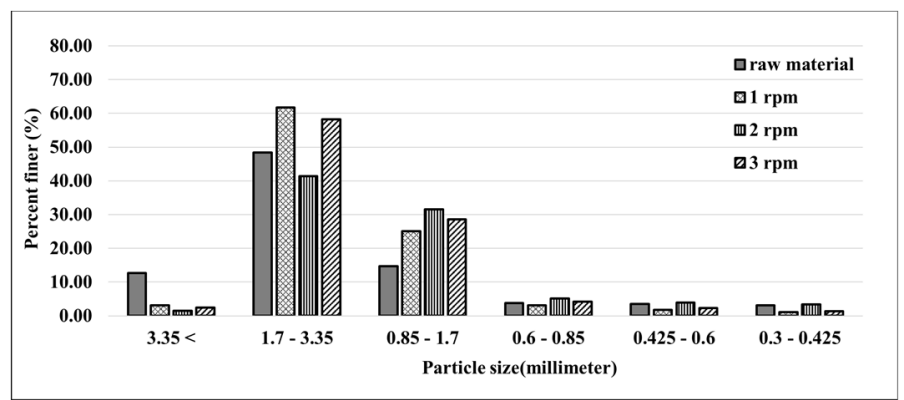

(f)

Figure 6: Continued.

Table 3: Calorific value.

\begin{tabular}{|c|c|c|c|}
\hline Rotational speed (rpm) & Temperature $\left({ }^{\circ} \mathrm{C}\right)$ & HHV (MJ/kg) & Energy yield (\%) \\
\hline \multirow{3}{*}{1} & 230 & 25.53 & 61.27 \\
\hline & 250 & 26.27 & 55.82 \\
\hline & 270 & 25.40 & 44.64 \\
\hline \multirow{3}{*}{2} & 230 & 25.53 & 65.45 \\
\hline & 250 & 27.50 & 59.90 \\
\hline & 270 & 28.20 & 57.51 \\
\hline \multirow{3}{*}{3} & 230 & 26.63 & 71.51 \\
\hline & 250 & 27.57 & 66.72 \\
\hline & 270 & 28.60 & 60.10 \\
\hline \multicolumn{2}{|c|}{ Raw material } & 17.40 & - \\
\hline
\end{tabular}

\subsection{Mass yield and energy yield}

The effect of torrefaction temperature on mass yield and energy yield at 1, 2, and $3 \mathrm{rpm}$ were investigated, as shown in Fig. 7. The torrefaction temperature had more impact on mass yield. The mass yield of torrefied products was decreased when the torrefaction temperature was increased. Moisture content and volatile matter were removed. The degradation was a decomposition reaction of cellulose, hemicellulose, and lignin in biomass. The highest mass yield was $46.72 \%$ at $3 \mathrm{rpm}$ with $230^{\circ} \mathrm{C}$. A similar trend of results was reported for other 
biomass types [15], [16]. The energy yield was indicated the improvement of torrefied biomass. After the torrefaction process, the heating value of torrefied biomass was an increase. The energy yield was shown a trend similar to the mass yield. The energy yield of torrefied biomass was decreased when the torrefaction temperature increase. The highest energy yield was found to be $71.51 \%$ at $3 \mathrm{rpm}$ with $230^{\circ} \mathrm{C}$. A similar result has also been observed by others [17], [18].

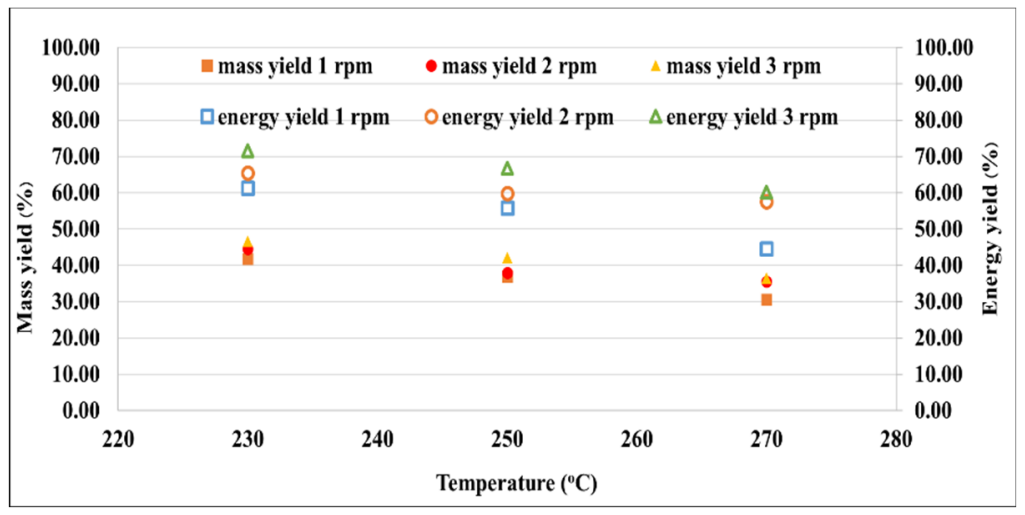

Figure 7: Effect of torrefaction temperature on mass yield and energy yield.

The effect of rotation speed on mass and energy yield was shown in Fig. 8. The mass yield of torrefied biomass increased with increasing rotation speed. At the high rotation speed, the residence time of biomass in the rotary kiln was less than the low rotation speed. At low rotation speed, moisture content and the volatile matter were removed more than high rotation speed. The energy yield was shown a similar trend to the mass yield. The energy yield of torrefied biomass increased when the rotation speed increase. The highest mass yield and energy yield were found at $230^{\circ} \mathrm{C} 3 \mathrm{rpm}$ with $46.72 \%$ and $71.51 \%$, respectively.

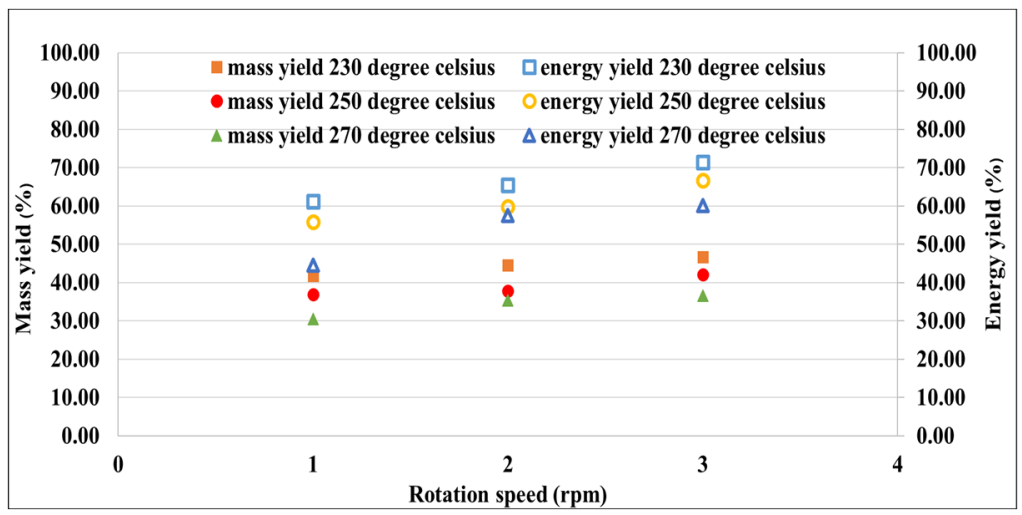

Figure 8: Effect of rotational speed on mass yield and energy yield.

The optimum condition for torrefaction with rotary kiln was $3 \mathrm{rpm} 230^{\circ} \mathrm{C}$. At $230^{\circ} \mathrm{C}$, the yield of a solid particle was more than other temperatures. Moisture content and particle size 
of torrefied biomass decreased. The HHV of torrefied biomass increased. The mass yield and energy yield decreased when the torrefaction temperature was increased. The mass yield and energy yield increased when rotation speed was an increase. The highest mass yield and energy yield were found at $3 \mathrm{rpm} 230^{\circ} \mathrm{C}$.

\section{CONCLUSIONS}

The pilot-scale rotary kiln for the torrefaction process was established and used for the torrefaction process. The solid phase product was decreased when the torrefaction temperature increased, and the fluid phase product and gas-phase product were increased. The particle size after torrefaction was smaller than raw biomass. The mass yield and energy yield decreased when the torrefaction was increase. On the other hand, the mass yield and energy yield increased when rotation speed was an increase. It was concluded that the optimum condition in this research was $230^{\circ} \mathrm{C}$ with $3 \mathrm{rpm}$. The torrefaction process can improve the properties and combustion performance of biomass. The Palm kernel shell was a suitable fuel and co-burning in the economic energy plant in the torrefaction process with the optimum condition.

\section{ACKNOWLEDGEMENTS}

The authors wish to acknowledge the financial support from the Department of Mechanical Engineering, Faculty of Engineering and Industrial Technology and Silpakorn University Research, Innovation and Creative Fund.

\section{REFERENCES}

[1] González Martínez, M. et al., Understanding the torrefaction of woody and agricultural biomasses through their extracted macromolecular components. Part 1: Experimental thermogravimetric solid mass loss. Energy, 205, 2020.

DOI: $10.1016 /$ j.energy.2020.118067.

[2] Niu, Y. et al., Biomass torrefaction: properties, applications, challenges, and economy. Renewable and Sustainable Energy Reviews, 115, 2019.

DOI: 10.1016/j.rser.2019.109395.

[3] Ru, B., Wang, S., Dai, G. \& Zhang, L., Effect of torrefaction on biomass physicochemical characteristics and the resulting pyrolysis behavior. Energy and Fuels, 29(9), 2015. DOI: 10.1021/acs.energyfuels.5b01263.

[4] Chutwiboonkun, N., Kositchaimongkol, S. \& Tharawadee, N., The effect of lifters, inclination angle and rotational speed on residence time of rotary kiln for torrefaction process. Defect and Diffusion Forum, 407, 2021.

DOI: 10.4028/www.scientific.net/DDF.407.121.

[5] Colin, B., Dirion, J.L., Arlabosse, P. \& Salvador, S., Experimental study of wood chips torrefaction in a pilot scale rotary kiln. Chemical Engineering Transactions, 37, pp. 505-510, 2014. DOI: 10.3303/CET1437085.

[6] Dirgantara, M., Karelius, K., Cahyana, B.T., Suastika, K.G. \& Akbar, A.R.M., Effect of temperature and residence time torrefaction palm kernel shell on the calorific value and energy yield. Journal of Physics: Conference Series, 1428(1), 2020.

DOI: $10.1088 / 1742-6596 / 1428 / 1 / 012010$.

[7] Saelor, S., Kongjan, P. \& O-Thong, S., Biogas production from anaerobic co-digestion of palm oil mill effluent and empty fruit bunches. Energy Procedia, 138, pp. 717-722, 2017. DOI: 10.1016/j.egypro.2017.10.206. 
[8] Chen, D., Zhou, J., Zhang, Q., Zhu, X. \& Lu, Q., Torrefaction of rice husk using TGFTIR and its effect on the fuel characteristics, carbon, and energy yields. BioResources, 9(4), pp. 6241-6253, 2014. DOI: 10.15376/biores.9.4.6241-6253.

[9] Zhang, S., Chen, T., Xiong, Y. \& Dong, Q., Effects of wet torrefaction on the physicochemical properties and pyrolysis product properties of rice husk. Energy Conversion and Management, 141, 2017. DOI: 10.1016/j.enconman.2016.10.002.

[10] Chen, D., Gao, A., Ma, Z., Fei, D., Chang, Y. \& Shen, C., In-depth study of rice husk torrefaction: Characterization of solid, liquid and gaseous products, oxygen migration and energy yield. Bioresource Technology, 253, 2018.

DOI: 10.1016/j.biortech.2018.01.009.

[11] Chen, D., Chen, F., Cen, K., Cao, X., Zhang, J. \& Zhou, J., Upgrading rice husk via oxidative torrefaction: Characterization of solid, liquid, gaseous products and a comparison with non-oxidative torrefaction. Fuel, 275, 2020. DOI: $10.1016 /$ j.fuel.2020.117936.

[12] Asadullah, M., Adi, A.M., Suhada, N., Malek, N.H., Saringat, M.I. \& Azdarpour, A., Optimization of palm kernel shell torrefaction to produce energy densified bio-coal. Energy Conversion and Management, 88, 2014.

DOI: 10.1016/j.enconman.2014.04.071.

[13] Junga, R., Pospolita, J. \& Niemiec, P., Combustion and grindability characteristics of palm kernel shells torrefied in a pilot-scale installation. Renewable Energy, 147, pp. 1239-1250, 2020. DOI: 10.1016/j.renene.2019.09.060.

[14] Mei, Y. et al., Torrefaction of cedarwood in a pilot scale rotary kiln and the influence of industrial flue gas. Bioresource Technology, 177, pp. 355-360, 2015.

DOI: 10.1016/j.biortech.2014.10.113.

[15] Wang, M.J., Huang, Y.F., Chiueh, P.T., Kuan, W.H. \& Lo, S.L., Microwave-induced torrefaction of rice husk and sugarcane residues. Energy, 37(1), pp. 177-184, 2012. DOI: 10.1016/j.energy.2011.11.053.

[16] Li, S.X., Chen, C.Z., Li, M.F. \& Xiao, X., Torrefaction of corncob to produce charcoal under nitrogen and carbon dioxide atmospheres. Bioresource Technology, 249, pp. 348-353, 2018. DOI: 10.1016/j.biortech.2017.10.026.

[17] Soponpongpipat, N., Nanetoe, S. \& Comsawang, P., Thermal degradation of cassava rhizome in thermosyphon-fixed bed torrefaction reactor. Processes, 8(3), p. 267, 2020. DOI: $10.3390 / p r 8030267$.

[18] Soponpongpipat, N., Nanetoe, S. \& Comsawang, P., Thermal and torrefaction characteristics of a small-scale rotating drum reactor. Processes, 8(4), p. 489, 2020. DOI: $10.3390 /$ PR8040489. 